\title{
Multimedia College English Teaching: Defects and Countermeasures
}

\author{
Chuanzhen $\mathrm{Wu}$ \\ Yantai Engineering and Technology College, Yantai, Shandong, 264006, China \\ Email: talkshow2000@eyou.com
}

\begin{abstract}
It is a widely accepted belief among college English teachers who have tried Multimedia college teaching that college English teaching under the circumstance of Multimedia makes the English classroom a fascinating place. However, the defects of Multimedia college English teaching are born with its advantages over traditional college English teaching. The present writer intends to make an analysis of its defects and provide feasible countermeasures.
\end{abstract}

Index Terms - multimedia, college English teaching, defects, countermeasures

\section{INTRODUCTION}

From the study on linguistics, psychology, physiology and technology (Yang, 2005), we may conclude that computer and Multimedia technology superbly adapt to college English teaching in that it can provide sound, color, graphics, animation, video, and net information---in addition to text---in a matter of second and can satisfy the variety of learning preference or styles, and can deploy different neuro-systems in learning. It is a widely accepted belief among college English teachers who have tried Multimedia college teaching that college English teaching under the circumstance of Multimedia makes the English classroom a fascinating place.

Though, will Multimedia solve all the problems in college English teaching? Will it be another wonder drug, as some people described AV instruction in language teaching in1970s?

Media is media, and there is no wonder drug in language teaching. The defects of Multimedia college English teaching are born with its advantages over traditional college English teaching. "Only when media is subjected to careful consideration and application, can an ideal instructional effect be achieved" (Mei, 1998, P. 13).

For college English teachers, the comprehensive awareness of the defects of Multimedia as well as the countermeasures is of great importance in the application of the new technology to college English teaching.

\section{Defects of Multimedia College English Teaching}

\section{A. Teachers' Factors}

Either in traditional classrooms or in Multimedia classrooms, the teacher has a large and very important role to play in the teaching-learning process. The most important factor for class effectiveness is teacher's quality. What teachers need to be? "Principals and personnel directors, for the most part, agree on the basis for effective teachers--- qualities

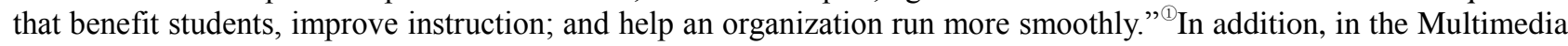
classroom, the mass of language data available to students is overwhelming and needs to be filtered and systematized so that students actually will be able to make sense of it.

However, the defects of Multimedia somehow hamper the development of teachers' role in the Multimedia classroom and consequently teachers fail to make the most of the Multimedia classroom though they are facilitated with considerable teaching practice.

1. Routine Work in Instruction

Multimedia itself is not liable for the form and development of teachers' routine work in instruction in Multimedia teaching. The responsibility lies in college English teachers.

One of the significant characteristics of Multimedia is that by the instrumentality of floppy disk, hard disk, software, CD-ROM, video and the Internet etc., it can lessen the burden of teachers' meaningless and repetitive work and increase teachers' investment in class. "If you are enthusiastic about teaching, show it! Make learning fun. Your eagerness for teaching will make a difference in the motivation of your students. Beyond the classroom, it helps build a sense of teamwork. Enthusiasm is contagious."(2)

However, the advantage of Multimedia technology, unfortunately, leads to some teachers' dependence on it. In class they fail to show enthusiasm and creation. In some sense, they turn the Multimedia classroom into an expensive bore and what they act in class is nothing but a new generation of button-pusher. Undoubtedly, the lack of creation and

\footnotetext{
(1) http//www.teachingforexcellence.com

(2) http//www.teachingforexcellence.com
} 
enthusiasm makes no sense of the technology-enhanced classroom.

2. Poor Classroom Management

Effective teachers are actively involved in classroom management. "They move around. They don't stand around but are busy. They are actively involved with students and other staff.")

In Multimedia classrooms, classroom management is not easy to conduct because English teachers are busy with the operation of the machine and with the instruction of the language. What's more, in most cases, teachers are sitting in front of the computer and seldom have a chance to move around. In the classroom which has a poor and unscientific layout, the teacher sitting in the front of the classroom can hardly see students at the back rows. In this case, classroom management is hard to be realized.

3. Loss of Affection

Education is a people business and it is imperative to attract students through good human relation skills. "If people don't like your behavior as a teacher, they will not want to be around you, much less perform for you."( ${ }^{(1)}$ The affection built up between college English teachers and students plays an important role in class behavior and latter study.

In the Multimedia classroom, however, the affection between the teacher and students seem to be in danger. On the one hand, teachers are busy with machine operation---computer, VCD/DVD player, overhead projector, courseware, and the change of desktop windows etc---which might even get the proficient teachers busy, let alone those unskilled. On the other hand, sitting in front of the machine without moving about, gesture, eye contact, and body language which are all regarded as vital in class tends to make English class "cool" and the tie between the teacher and students becomes loose and it seems to students that the teacher is caring about the machine and students are focusing on the screen. Thus, the affection, which used to play an important role in class, seems to be dying.

4. Waste by Haste

The amount students learned is related to the opportunity they are given to learn. Students learn the most by doing, not by being fed, or standing in line or sitting motionless. The college English class in Multimedia classroom, however, is conducted in a rush and students seldom get a chance to have their say. What they can do is waiting for the information on the screen. Many reasons result in this phenomenon. One of the main reasons is that teachers get too many things to share with students and at the same time they have little time at their free disposal. Another reason is that the college English class is not well organized and designed. College English teachers may bear this proverb in their mind while preparing and delivering the lesson: Haste makes waste.

\section{B. Learners' Factors}

1. Test on Students' Learning Autonomy

Compared with traditional English classrooms, in Multimedia classrooms, more information and resources are available and presented to students. This is considered to be one of the advantages of Multimedia college English teaching. But more language resources do not mean more effective learning. In this sense, students' learning autonomy is being tried. For example, in class when video films are used, both visual and audio information are shown to students. On this occasion, it is up to students to study the detailed information and select those they think important. However, the present college students are the products of modern education system in which learning autonomy is somehow neglected. So in video classes, most of them are watching only for fun, or are only waiting for the target aspects of language instruction from the teacher. In a word, students' wait-to-be-fed habit interrupts the effect of Multimedia language teaching.

\section{Physical Fatigue}

Presently, there are two kinds of Multimedia classroom: one is the classroom in which everybody operates on a Multimedia PC; the other one is called one-computer Multimedia classroom. No matter which kind of classroom students are in, physical fatigue caused by Multimedia classroom is worth our attention. More than $42 \%$ of the interviewees in the open interview (Yang, 2005) admit that the computer screen strains their eyes after watching for about 30 minutes. More than 53\% of them feel unwell of their waist and neck after staring at the screen for about 30 minutes. Undoubtedly, the physical fatigue to some extent has a negative effect on students' study.

\section{Technological Factors}

\section{Technology of Multimedia Classrooms}

In most universities and colleges, Multimedia is still a new concept. For the AV instruction staff, defects in the design of room layout, installation of facilities, lighting and airing seem to be inevitable because of the lack of experience. For example, for the convenience of students' watching, lecture theatre is preferred by students. But unfortunately, many traditional classrooms are transformed into Multimedia ones by merely facilitating them with certain equipment. In this case, the teacher sitting in the front cannot see the students at the back rows and students at the back rows fail to see the screen clearly and completely.

2. Technology Required of College English Teachers

Currently, owing to the traditional education system, most college English teachers are not good at computer, and

\footnotetext{
(3) http//www.teachingforexcellence.com

(4) http//www.teachingforexcellence.com
} 
some of them are even not proficient in typing. This causes great trouble in the design of courseware and application of Multimedia devices. The unskilled operation on computer would inevitably affect the instruction flow, which in turn would de-motivate students if it happens frequently in class. On the other hand, the defects in the presently-used CD-ROM for college English teaching reinforce the operation difficulty for teachers.

3. Technology of Network

Thanks to the fantastic spurt of IT, network, both the Internet and the Local Area Net, is changing with each passing day. More and more practical resources of English teaching and learning can be easily located and are available for college English teaching. Nevertheless, the defects existing in network prevent it from steady and secure application. First, "not everything is on the Internet. For example, only about $8 \%$ of all journals are on the web, and an even smaller fraction of books are there. Both are costly!" (5) Second, "It's really a needle in the haystack. The needle is your search, the haystack is the web." ${ }^{(6)}$ Third, Quality control doesn't exist. Some insecure connection to X-rated sites or the information alike might be another reluctance for teachers to use the Internet. Four, the Internet might be a mile wide but an inch (or less) deep. Not much on the Internet is more than fifteen years old. Vendors offering magazine access routinely add a new year while dropping an earlier one. Fifth, the too frequent breakdown of network would hinder the application of the Internet to English teaching and in some degree de-motivate students.

If these problems keep unsolved, it's somewhat hard to make the Internet an ideal tool for English teaching.

\section{COUNTERMEASURES}

Fortunately, the problems arising from the defects of Multimedia college English teaching do not seem to be incurable. If we conduct properly, many of the problems can be solved, or at least, some of the defects can be avoided or compensated to some extent.

First, responsibility is needed to breed into teachers' mind. Responsibility is the fundamental quality of teachers. If the teacher is of great sense of responsibility, he would know very well what to do to better the teaching-learning process and would know definitely why enthusiasm is needed in language class and would show it in class willingly. In this way routine work in instruction might be avoided and it makes creative and enthusiastic class possible.

Second, continual study and research is an indispensable part of qualified teachers' life. Only in this way can teachers keep up with their fields of expertise. What's more, the research and study enable teachers to find solutions to the problems arising in class. For example, how to promote the classroom management in Multimedia class? Should teachers sit in the front of the classroom all the way? Effective teachers would apply some alternatives to the class---group discussion, free talk, pair work, and teachers would move around occasionally, accompanied with some gestures and body language. Remember: efficient management allows teachers to spend more learning time with students and to engage students. Another thing for college English teachers to learn is the operation of the Multimedia PC and the making of courseware etc.

Third, flexibility is required in the process of teaching. Teaching requires flexibility. Adjust when timely topics come up instead of staying with the lesson plan. Be sensitive enough to students' needs and offer necessary help. Multimedia teaching does not mean sitting there and operating machine. It also involves flexibility. Do not stick to original plan when a bit flexibility might make the difference between boring and interesting. It is communicative skills with people that we are learning, not with machine. Flexibility is the precondition of affection between the teacher and students.

Fourth, universities and colleges may adopt reasonable curriculum. As for the instruction pace in Multimedia classrooms, reasonable curriculum might help some. According to the curriculum of most colleges, students have four hours of English class each week--- two for text and two for exercise. The arrangement makes intensive teaching like duck-feeding and both the teacher and students are on the run in the class. A little change might change the instruction pace from rush to walk.

Sixth, the school management personnel may better the physical condition of Multimedia classrooms. Coziness and cleanliness are typical of Multimedia classrooms. But, that's not enough for effective teaching and learning. Classrooms that are badly lit, poorly aired and overcrowded can be excessively de-motivating, but unfortunately many of them exist in colleges and universities. For the design of Multimedia classrooms, the installation of the screen, music box, the layout of the desks, and the light all should be taken into account. Generally speaking, lecture theatre classrooms are preferred because they enable students at the back rows to have a good view of the screen.

Last, definitely not the least, the training of AV instruction staff is very necessary. Multimedia college English teaching cannot be done without the assistance of AV instruction staff because most of the college English teachers are not good at Multimedia technology and operation. A minor breakdown might lead to the failure of class presentation. In addition, the application of network is still new to college English teachers, even to AV instruction staff. As a result, qualified AV instruction staff members are needed to maintain the machine, ensure the flow of the teaching process and guarantee the stability of network.

\section{CONCLUSION}

\footnotetext{
(5) http//www.eddigest.com

(6) http//www.eddigest.com
} 
If we college English teachers employ various techniques to make Multimedia classes motivating and interesting, if we labor along to explore appropriate pedagogy in Multimedia college English teaching, if we keep an eye on what's going on in our expertise, and if we take care to become dynamic stimulators rather than machine operators, we may be able to overcome the defects of Multimedia and fast-forward our students' learning. There is absolutely no doubt that Multimedia will play a more and more important role in college English teaching, with all the defects overcome and with proper pedagogy deployed.

\section{REFERENCES}

[1] Ellis, R. (2000).Second Language Acquisition. Shanghai Foreign Language Education Press, Shanghai.

[2] Harmer, J. (1983).The Practice of English Language Teaching. London and New York: Longman.

[3] Harmer, J. (2000). How to Teach English. Foreign Language Teaching and Research Press, Beijing.

[4] Howard, D.V. (1983). Cognitive Psychology. Macmillan Publishing Co. Inc. New York.

[5] Matlin, M.W. (1989). Cognition. Rinehart and Winston, Inc. New York.

[6] Mayer, R.E. \& Lonn, S. (2001). Cognitive constraints on multimedia Learning. Journal of Educational Psychology, Vol. 93, No. $1,187-198$.

[7] Mei, Jiaju. (1998). Two stages of modern instruction technology in China. Computer-assisted Foreign Language Education, No. $1,12-15$.

[8] Moreno, R. \& Mayer, R.E. (2000). A coherence effect in multimedia learning. Journal of Educational Psychology, Vol. 92 , No.1, 117-125.

[9] Neill, S. \& Casewell, C. (1993). Body Language For Competent Teachers. Routledge, London.

[10] Yang, Qingbo. (2005). Multimedia English Teaching: From Theory to Practice. Jilin People's Press, Changchun.

Chuanzhen Wu was born in Yantai, China in 1968. She received her M. A. degree in psychology from Ludong University, China in 2007.

She is currently a lecturer in Yantai Engineering and Technology College and her research interest include EFLT and applied psychology. 